\title{
Comparative study on lesions of reproductive disorders of cows and female dromedary camels slaughtered at Addis Ababa, Adama and Akaki abbatoirs with bacterial isolation and characterization
}

\section{Aynalem Mandefro ( $\nabla$ anaafman@gmail.com )}

Hawassa University College of Natural and Computational Science

Tilaye Demissie Ayana

Addis Ababa University

\section{Gemechu Chala Hunderra}

Hawassa University

Tadesse Gidey Gebrezihar

Addis Ababa University

\section{Bulto Giro Boru}

Addis Ababa University

\section{Natnael Teshager Desta}

National Animal HealthDiagnostic and Investigation center, Sebeta, Ethiopia

\section{Research article}

Keywords: Cow, Dromedary camel, lesion, reproductive organ

Posted Date: September 3rd, 2020

DOI: https://doi.org/10.21203/rs.3.rs-35515/v2

License: (c) (i) This work is licensed under a Creative Commons Attribution 4.0 International License. Read Full License

Version of Record: A version of this preprint was published at BMC Veterinary Research on March 29th, 2021. See the published version at https://doi.org/10.1186/s12917-021-02822-z. 


\section{Abstract}

Background: Reproduction is a basic prerequisite to efficient livestock production. Reproductive performance depends upon the normal structure and function of genital organs.

Methods: A cross-sectional study was conducted from November 2016 to May 2017 to identify and compare the frequency of pathological lesions in the reproductive tract and to isolate bacteria associated to uterine lesions in female dromedary camels and cows slaughtered at Akaki camel slaughter house and Addis Ababa and Adama municipal abattoirs. Purposive sampling technique was used to collect 280 reproductive tracts from cows and female dromedary camels. Following gross inspection at abattoirs, tissue samples with lesion were collected for histopathological and bacteriological investigation.

Result: Various pathological lesions with different degrees of severity were observed in 48 (34.2 \%) and 51 (36.4\%) of dromedary camels and cows, respectively. Uterine lesions were the most prevalent $(21.4 \%)$ lesions observed in dromedary camels followed by ovarian lesions (7.14\%); while in cows, ovarian lesions were the major prevalent (16.4\%) lesions followed by uterine lesion (14.2\%). The result showed that there were 56 bacteria isolated from cows uterine lesion with Staphylococcus species (28.5\%), Streptococci species (19.6\%), Coynebacterium species (8.9\%), Escherichia coli (26.78\%), Salmonella species (10.7\%) and Klebsiella species (5.35\%) being the prominent isolates; while in camels, there were 45 bacteria isolated with Escherichia coli (35.5\%), Staphylococcus species (26.6\%), Streptococcus species (13.3\%), Pseudomonas species (6.6\%), Proteus species (4.4\%), Salmonella species (8.8\%) and Klebsiella species (4.4\%) being the most frequently isolated. The result showed that the major isolates were similar with slightly higher in cows.

Histopathologically, endometrial glands degeneration, sloughing of epithelium, peri-glandular cuffing and infiltrations of inflammatory cell were some of characteristic changes observed in uterus.

Conclusions: Pathological lesions in reproductive organs in female dromedary camels and cows showed great prevalence, with similarity in bacterial isolates between the two species. The role of each reproductive lesions and bacterial isolates incriminated as causes of reproductive failures in this livestock species needs further investigation.

\section{Background}

Reproduction is a basic prerequisite to efficient livestock production. The fact that productivity of animals largely depends on their reproductive performance, regular and successful reproduction is a key to profitable animal production. Large animals that rarely deliver a live calf are not worth keeping [1]. Therefore, reproductive efficiency is an important facet for achieving maximum return from the animal [2]. Reproductive performance of a given animal depends upon the normal structure and functions of genital organs [3]. However, the physiological process of reproduction could get disrupted due to a variety of factors like nutritional deficiencies, specific and non-specific infections, hormonal abnormalities, immunological malfunctions and environmental stress [4]. Thus, identification of reproductive tract diseases is important, especially, when we dealing with genetically superior animals [5]. Reproductive diseases are considered as an important contributor to the decline in fertility potential in the large farm animals. Generally, in large farm animals, the highest incidence of infertility might result in decreased milk production, treatment costs, extra labor and increased rate of culling [6].

Pathological lesions of the female genital tract are believed to be the major reason for economic losses associated with infertility, culling and slaughtering of cows $[7,8,9]$ and in dromedary camels $[10,11]$. In general, female animals are culled and sent to slaughterhouse either they are uneconomic to maintain or else they have chronic or untreatable diseases. Hence, abattoirs are a good source for studying pathological lesions of reproductive organs that are severe enough to cause infertility and even sterility [12]. Moreover, most female reproductive organ pathological lesions lack additional outward manifestations. Therefore, most of these abnormalities can only be diagnosed when the animal is 
subjected to postmortem examination [13]. Thus, examination of gross and microscopic lesions of genital tract play a central role in the identification of these problems.

Previously, abattoir-based studies on reproductive organs abnormalities of cows have been documented elsewhere in Ethiopia. $[1,7,8,9,14]$. Ovariobursal adhesion, follicular cyst, luteal cyst, paraovarian cyst, ovarian hypoplasia, vaginitis, cervicitis, hydrosalpinx, pyosalpinx, hydrometra, endometritis, cervical ring hypoplasia and hypoplasia of the uterus were some of the characteristic pathological lesions recorded in most of the above studies. Similar findings were also been reported from other parts of the world $[15,16,17]$. In Ethiopia, however, limited documented information is available regarding female dromedary camels' reproductive organs lesions [11]. Nevertheless, studies from other parts of the world have reported different reproductive pathological lesions of uterus, ovary, oviduct, cervix and vagina. Among those, lesions of uterus were the most frequent in almost all studies [6, 18-22].

The inappropriate use of antimicrobials and corticosteroids for the treatment of reproductive disorders or for the management of retained placenta and other obstetrical procedures in camels and cows favored bacterial contamination of vagina and the subsequent invasion of the uterine environment $[23,24]$. Studies have shown that uterine infection is a significant cause of reproductive failure and infertility in both dromedary camelids [5] and cows [25]. On the other hand, in cows, bacterial pathogens are associated with delayed uterine involution and failure to conceive on one or more cycles in the same season $[24,26]$. The most common and economically important bacteria for uterine infection in both dromedary camelids and cows are Actinomyces species, Escherichia coli, Fusobacterium species, Pasteurella species, Pseudomonas species and Staphylococcus species. [26, 27].

Reproductive inefficiency in animals due to observed pathological lesions of female genitalia causes huge economic loss to farmers. To circumvent the problem, isolation of bacteria from uterus and histopathological investigations of each lesion are critical for diagnosis and management of poor reproductive performances in animals. Most of the studies reported previously were based on gross pathological lesions observation and were done either on cows or female dromedary camels. Comparative studies on pathological lesions in reproductive tract, isolation and identification of bacteria involved in uterine disorder were very few in general and were not yet attempted in Ethiopia. Therefore, to narrow these gaps, the current study was aimed to identify and compare the types and frequencies of reproductive organ pathological lesions between cows and female dromedary camels; describe and characterize gross and microscopic lesions of observed abnormalities. Additionally, the study also tried to isolate and identify aerobic bacteria associated with uterine lesions in both cows and female dromedary camels.

\section{Methods}

\section{Study design, study area and study population}

A cross-sectional study was conducted from November 2016 to May 2017 in Addis Ababa and Adama Municipal abattoirs, and Addis Ababa Akaki Kality camel slaughter house. Addis Ababa municipal abattoir is located at the central part of Addis Ababa whereas Akaki camel slaughter house is located in the south-eastern outskirt of Addis Ababa at 20 $\mathrm{Km}$ away from the center of Addis Ababa. Adama municipal abattoir is located in Adama town of Oromia regional state at about $99 \mathrm{Km}$ away from the center of Addis Ababa.

The study population were female dromedary camels slaughtered at Addis Ababa Akaki camel slaughter house and cows slaughtered at both Addis Ababa and Adama Municipal abattoirs. In these abattoirs and camel slaughter house, all cows and female dromedary camels included in to this study were brought to abattoirs for the fact that they were either aged and are not no more productive or have a history of reproductive failure (due to various reasons like repeated breeding, anestrous, abortion, chronic mastitis). In these abattoirs only few or even no cows were slaughtered per day which was also true for female dromedary camels. Taking this in to consideration, the current study was purposively 
targeted and included all cows slaughtered at both municipal abattoirs and female dromedary camels slaughtered at Akaki camel slaughter house during the study period.

Abattoir visit and sample collection was done only once per week for 28 weeks for both cows and female dromedary camels in order to have a sufficient time for sample processing at the laboratory. On average, three to seven animals (for both species) were slaughtered in each abattoir. All slaughtered cows and female dromedary camels were considered for the study. Accordingly, a total of 280 animals (140 female dromedary camels and 140 cows) were slaughtered and examined during the study period for which tissue samples with grossly visible lesions were collected for histopathological and bacteriological examinations. Holstein-Friesian, crossed breed (mixed breed of local Borena and Holstein-Friesian) and local (Borena, Zebu, Arsi-Bale and Harar) breeds of cows were included in to the study.

Age, body condition score and origin of animal were gathered during ante mortem examination. Age of female dromedary camels was estimated by dental examination on the basis of their dental formulas and tartar deposition on the teeth as described in Mohammed et al. [6]. However, cow's age was estimated according to Puck and Soliame [28]. Accordingly, age of animals was categorized as $<5$ years as young, 6-11 as adult and $>11$ as old in both species of animals. The animals' body condition score (BCS) was evaluated on a scale of 0 to 5 by considering visual examination and fat cover palpation over the animal body following the description by [29]. Therefore, animals were categorized as poor for $\leq 2$, as medium for $\leq 3$ and as good for $\geq 4$ of measurement scale.

\section{Sample collection and processing}

During postmortem examination the entire reproductive tract was carefully removed intact from the pelvic cavity within 10-20 minutes of slaughter and placed on a sterile tray and taken to one corner of the abattoir, and visually examined and thoroughly palpated. A total of 280 reproductive tracts ( 140 from cows and 140 from dromedary camels) were obtained and studied during this study period. Each reproductive tract was opened along its longitudinal axis starting from the vagina down to the horns using sterile scissors and was observed for any abnormalities of color, odor, consistency and morphology $[30,9]$. Those with obvious gross lesions were noted based on their appearance, type, location and frequency of occurrence as previously described by Jenberie et al. [31]. Tissues with grossly visible lesions were sampled for histopathological and bacteriological examinations. Samples for bacteriological examination were collected only from affected uterus of both cows and dromedary camels. For histopathology, a tissue cut of 1-2 cm from the margins of apparently normal and affected parts were collected into a universal bottle containing $10 \%$ buffered formalin according to Talukder [32] and then transported to National Animal Health Diagnostic Investigation Centre for histopathological processing.

For bacteriological examination, the surface of the uterus with lesions were decontaminated by a flame and pieces of tissue from active lesion at the boundary were collected aseptically using sterile forceps, scissors and scalpel blade and placed into screw capped universal bottles containing sterile saline water [33]. Additionally, a sterile cotton swab was used to collect a drag swab samples from the active lesion of uterine surface right after visual examination and prior to tissue sample collection. The swab was then placed in a $50 \mathrm{ml}$ falcon tube containing a sterile peptone water for transportation. All the collected samples were labelled, tightly closed and placed in cool box containing ice packs and transported to the veterinary microbiology laboratory of Addis Ababa University College of Veterinary Medicine and Agriculture for culturing within 1-2hrs of collection. and all bacteriological processes were conducted within 6-8hrs of sample collection.

All laboratory bacteriological procedures were performed within 6-10hrs of sample collection and processed according to the previously established protocols by Quinn et al. [33]. Briefly, tissue samples were cut into pieces and inoculated in to the brain heart infusion broth and aerobically incubated at $37^{\circ} \mathrm{C}$ for $24 \mathrm{hrs}$. Same broth was also inoculated directly with 
the collected swabs and aerobically incubated at $37^{\circ} \mathrm{C}$ for $24 \mathrm{hrs}$. Tubes were then observed after $24 \mathrm{hrs}$ of incubation for growth (turbidity) and a loop-full of the suspected culture was streaked parallel on sheep blood agar (7\%) and MacConkey agar and incubated aerobically at $37^{\circ} \mathrm{C}$ for another $24 \mathrm{hrs}$. The blood agar plates were checked for presence of growth, hemolysis (types), colony morphology, size and shape. MacConkey agar plates were also checked for presence of growth, lactose fermentation and for colony morphology, size and shape. For primary identification, gram stain, catalase, oxidase and motility tests were conducted. Selective and differential media such as Mannitol salt agar, Edwards medium, Eosine methylene blue and Salmonella shigella agar were used for the suspected samples from the primary test results. After $24 \mathrm{hrs}$ of incubation, characteristic growth on selective medium was registered after which a colony was then further inoculated in to nutrient broth for further biochemical tests. In general, coagulase, indole, Methyl red (MR), Vogues-Prousker (VP), Citrate, Urease, Lysine and Triple Sugar Iron (TSI) tests were performed as secondary biochemical tests.

For histopathological tissue examination, tissue specimens were processed using standard procedures of tissue processing, described by Talukder [32]. Tissues obtained from the abattoirs were further trimmed at the laboratory and were routinely processed for paraffin-embedding and hematoxylin-eosin routine staining in 4 - $5 \mu \mathrm{m}$ sections. Stained slides were examined under microscope (at 10 x, 40x and 100x magnification) using a phase contrast microscope (Nikon, Japan) and photomicrographs were taken.

\section{Data analysis}

A database was created on spreadsheet of Microsoft Excel, 2010 and STATA version 13 statistical software was used for descriptive analysis. Descriptive summary statistics (frequencies and cross-tabulation) were computed for pathological lesions and uterine bacterial isolates prevalence. Uterine bacterial isolates were compared between species using descriptive analysis. Qualitative method was used to describe gross and histopathological lesions and findings.

\section{Results}

The detail of observed lesion types with frequencies was shown on Table 1, 2 and 3 below. During the study period, a total of 280 reproductive tracts (140 from cows and 140 from female dromedary camels) were collected and examined. Of the 280 reproductive tracts, 48 (34.2\%) and 51 (36.4\%) diseased reproductive tracts were observed in female dromedary camels and cows, respectively. Comparatively, the most frequently observed reproductive tract lesions in dromedary camels were uterine abnormalities (21.4\%) followed by ovarian lesions (7.14\%) (Figure 1). However, in cows, ovarian lesions were the most (16.4\%) frequently observed followed by uterine lesions $(14.2 \%)$. Vaginal lesions were observed more (2.85\%) frequently in dromedary camels than cows (1.42\%) (Figure 1).

\section{Ovarian Abnormalities}

Different ovarian abnormalities were observed in 23 (16.4\%) and 10 (7.14\%) of examined cows and female dromedary camels, respectively. Collectively, follicular cyst, luteal cyst, inactive ovary, paraovarian cyst, ovarian bursal adhesion, Oopharitis and hydrobursitis were observed (Table 1). Ovarian bursal adhesion and Oopharitis were observed only cows whereas hydrobursitis was seen only in dromedary camel.

Follicular cysts were seen in (4.2\%) and (2.85\%) of examined cows and dromedary camels, respectively. The lesions were unilateral in both species. Three of them were on the right while the other three were on the left ovary in cows, but in dromedary camel only one was on the right and the rest three were on left ovary. Macroscopically, most of the cysts were spherical in shape and were occupying ovarian cortex in both species. Their diameters were ranged from $30 \mathrm{~mm}$ to 55

Page 5/24 
$\mathrm{mm}$ and the walls of the cysts were thin, slightly opaque and had straw colored serous fluid. One follicular cyst was accompanied by ipsilateral inactive ovary and endometritis in a cow (Figure 2A). Microscopically, the follicular cysts were lined by few layers of granulosa cells, as large portion of the granulosa cells were degenerated due to the pressure exerted by follicular fluids. It was difficult to differentiate the theca interna from the theca externa as the cells were compressed by fluid pressure (Figure 2B). Moreover, larger cysts caused pressure atrophy of the adjacent ovarian tissues and led the ovum and the surrounding cells completely degenerated or absent.

Luteal cysts were observed in (2.14 \%) and (1.42 \%) of examined cows and dromedary camels, respectively. In cows, two cysts were on the right ovary and one on the left. In dromedary camels, all cysts were observed on the right ovary. Macroscopically, the luteal cysts were thick walled, opaque and have meat like consistency. The wall of the cyst was lined by a whitish brown or yellow membrane. Furthermore, in cows, all the luteal cysts appeared as a single rounded mass on the surface of the ovary. In one camel multiple luteal cyst were observed. The diameter of the luteal cysts ranged from 20-25mm (Figure 3A). Microscopically, the wall of the luteal cysts was formed from thick layer of lutein cells and fat containing granulosa cells. They contained homogenous eosinophilic structure mixed with some luteal cells in the lumens.

The frequency of occurrence of paraovarian cysts was $2(1.4 \%)$ in each examined cows and dromedary camels. Macroscopically, the cysts were detected unilaterally only on the left ovary in both species. The cysts were located either in mesovarium or in mesosalpinx ligament. These cysts were $10-20 \mathrm{~mm}$ in diameter and transparent, having thin wall and contained clear watery fluid.

Ovarian hydrobursitis was observed in $(0.71 \%)$ of examined dromedary camel but, none of this lesion was observed in examined cow. The size of the affected bursa was about $5 \times 6.4 \mathrm{~cm}$ and the affection was unilateral. Moreover, the bursa was having about $25 \mathrm{ml}$ of accumulated watery and straw color fluid indicated in (Figure. 3B).

The frequency of occurrence of inactive ovary was $(2.85 \%)$ in cows and $(0.72 \%)$ in dromedary camels. It was bilateral and the ovary was very small, oval in shape and measured $1 \mathrm{~cm}$ by $1 \mathrm{~cm}$ in camel. In cows, all were unilateral with three of them on the right and one on the left ovary. The size varies from $1.6 \mathrm{~cm}$ by $1.1 \mathrm{~cm}$ to $1.5 \mathrm{~cm}$ by $1.0 \mathrm{~cm}$.

Macroscopically the ovaries were smaller in size, firmer in consistency and contained very small follicles on the surface of non-affected part. Microscopically, excessive fibrous connective tissue proliferation with complete absence of follicular or luteal developments was seen (Figure 4)

Oophoritis was observed only in a cow however, it was not seen in examined dromedary camels. This lesion might be incriminated in ovarian bursal adhesion as they accompanied each other. Macroscopically, the ovary was hyperemic and slightly swollen. Microscopically, the ovarian medulla was infiltrated by inflammatory cells (Figure. 5 A and B).

Ovariobursal adhesion was the most frequent (5\%) ovarian lesion encountered in cows. However, none was observed in dromedary camels. Expect for a single adhesion which was bilateral, all examined lesions were unilateral. Four of the adhesions were on the right and two on the left ovary. In one case ovariobursal adhesion was concomitantly occurred with oophoritis. Macroscopically, the ovaries were found adhered to the bursa and surrounded by a layer of connective tissue. The severity of adhesions varied from case to case. In five cows the adhesions were mild with sparse strands of connective tissue between the ovary and bursa. In two, the adhesions were intense in which, the ovaries were completely encapsulated in thick fibrous connective tissues.

\section{Uterine Abnormalities}

Uterine lesions were observed at high frequency 30 (21.4\%) than other disorders in dromedary camels, however, it was the second most frequently observed reproductive lesion in cows with a frequency of 20 (14.2\%). Microscopically, all uterine 
lesions with the exception of one, which found to be leiomyoma, were inflammatory in both species. Acute endometritis, chronic endometritis and catarrhal endometritis were common in both species. However, suppurative endometritis was observed only in cow's uteri (Table 2).

Acute endometritis was more frequent in dromedary camels than cows (Table 2). Acute endometritis was accompanied by luteal cyst in two of the dromedary camels. Macroscopically, the affected uteri were enlarged and the mucosa was either severely congested (red brown) or was severe reddening (Figure 6). Furthermore, thick blood tinged exudates were seen in the uterine lumen of three dromedary camels and one cow. Microscopically, endometrial epithelia were necrotized and sloughed in most cases with either congestion or hyperemia of endometrial blood vessels especially in basilar endometrial region. Moreover, polymorphonuclear cells, mainly of neutrophils were infiltrating the endometrium. Excessive peri-glandular cuffing of cells and atrophy of endometrial glands were characteristics of acute endometritis.

Suppurative endometritis were observed only in cows (1.42\%). Macroscopically, the endometrium was congested and covered with thick creamy white pus. The lesions were also further expanded to uterine horn but no pus observed in uterine horn. Microscopically, suppurative endometritis was characterized by infiltration of neutrophils into the endometrium with severe congestion of blood vessels and distortion of some endometrial glands.

Catarrhal endometritis was observed in two dromedary camels and two cows. Macroscopically, the uterus was enlarged and its mucosa was slightly congested, edematous and was covered by thick mucoid exudates. In one camel the mucoid exudates further expanded to cervix and vaginal mucosa discharged to outside of the body. The microscopic examination showed congestion of endometrial blood vessels, lymphocytic infiltration in the mucosa and submucosa with alternative areas of epithelial desquamation and hyperplasia of lining epithelium. Degenerations of endometrial glands were also seen.

Chronic endometritis was more frequent in dromedary camels than cows (Table 2). In one cow with chronic endometritis there was concomitant luteal cyst, vaginitis and cervicitis. Macroscopically, most of the uteri with chronic endometritis were thick, doughy, rigid, and their mucosa was severely congested. In one dromedary camel with chronic endometritis the uterus was severely congested, with corrugation of the perimetrium and dark brown hemorrhage on external surface (Figure. $8 \mathrm{~A}$ and $\mathrm{B}$ ).

Microscopically, the mesothelium of this uterus was hyperplastic with polypoid like projections and diffuse thickening of basal fibrous connective tissue. Most of the uteri affected by chronic endometritis were characterized by endometrial glandular degeneration, infiltration of mononuclear inflammatory cells mainly of lymphocytes, macrophages and to less extent neutrophils infiltrations. In some there was hyperplasia of endometrial epithelium (Figure $8 \mathrm{C}$ and D).

Only one uterine tumor was observed in a cow and was considered as uterine leiomyoma. No tumor was observed in dromedary camels. Macroscopically, the neoplasm was well-circumscribed, firmly attached on the body of the uterus with a diameter of $10 \mathrm{~cm}$ and a whorl-like and trabeculated on cut surface. Microscopically the leiomyoma was comprised of smooth muscle cells and connective tissue components. Largely, composed of interlacing (interweaving) bundles of smooth muscle fibers with acidophilic cytoplasm and elongated and rounded blunt ending nuclei. The fibers were usually fusiform or stellate in shape, possessed large, ovoid to elongated nuclei and sometimes multiple nucleoli. Slight pleomorphism, and little mitotic activity was also observed.

\section{Oviductal lesions}

Hemosalpinx was observed in one dromedary camel and three cows. In dromedary camel, it was unilateral and observed in the right oviduct. However, it was bilateral in one cow and unilateral in right oviduct in two cows. Macroscopically, in both species the oviduct was slightly enlarged in size and the mucosa was hyperemic and filled with blood. 
Microscopically, hyperplasia of the lining epithelium and congestion of blood vessels with inflammatory cellular infiltration were noticed (Figure 10).

Pyosalpinx was detected in one camel and two cows. Macroscopically, the affection was bilateral in both species. Moreover, the oviduct was enlarged and distended with pus. Pyosalpinx was accompanied with suppurative endometritis in one cow.

\section{Cervico-vaginal lesions}

Cervicitis was seen in two cows and two camels. In general, cervical lesions were observed with low incidence than the rest of reproductive organ abnormalities in both species (Table 3). Macroscopically, the cervix was slightly enlarged with congested and edematous mucosa that was covered with whitish viscous exudates.

Vaginitis was observed in $1(0.72 \%)$ and $2(1.42 \%)$ of examined dromedary camels and cows, respectively. Macroscopically, the mucosa appeared slightly swollen and showed diffuse, non-homogeneous congestion and hyperemia.

Vaginal lymphocytic myositis was observed in 3 (2.14\%) of examined dromedary camels and none was observed in cows. Moreover, in one of the three camels this lesion was accompanied by chronic endometritis. Macroscopically, in all the three camels the lesion was appeared as single, large sized (7-10 cm diameter) mass on the lateral side of the vagina

just cranial to the lips of the vulvar commeasure and on palpation the mass was soft. Microscopically, these lesions were characterized by huge lymphocyte infiltration into the smooth muscle fibers and some muscular degeneration. In some regions, the muscle fibers were necrotized and connective tissues were proliferated (Figure 11).

\section{Uterine lesions of cows and camels and bacterial isolates}

Fifty uterine tissue samples (30 from camels and 20 from cows) with acute, chronic, catarrhal and suppurative endometritis were cultured aerobically for bacterial isolation; 48 of which lead to bacterial isolates. Except for few bacteria which were isolated as pure culture, majority of the isolates were coupled with mixed bacteria. A total of 101 isolates were recovered, 56 out of them were from cows and 45 from female dromedary camels. Among bacterial pathogens isolated from cows, prevalence was so distributed; Staphylococcus species (28.5\%), Streptococci species (19.6\%), Coynebacterium species (8.9\%), Escherichia coli $(26.8 \%)$, Salmonella species $(10.7 \%)$ and Klebsiella species (5.4\%). In dromedary camels the most common isolates included E. coli (35.5\%), Staphylococcus species (26.6\%), Streptococcus species (13.3\%), Pseudomonas species (6.6\%), Proteus species (4.4\%), Salmonella species (8.8\%) and Klebsiella species (4.4\%). The common bacterial isolates identified from both species include Staphylococcus species, Streptococcus species, Escherichia coli, Salmonella species and Klebsiella species and these accounted more than $90 \%$ of isolated bacteria. Moreover, Pseudomonas species and Proteus species were isolated only from the camel uteri whereas, Corynebacterium species was only isolated from cows' uterus.

\section{Discussion}

Reproductive abnormalities play an important role in animal breeding either by causing infertility or sterility, and thus inflict heavy economic losses to the livestock owners. Animals with reproductive problems and low milk production are usually culled. For minimization of these losses, the important disorder of genital organs and their incidence must be defined [34]. Although previous reports claimed that camels are resistant to various disease conditions [35], the current study, however, revealed that the occurrence of most reproductive disorders was similar between the two species. In 
support of the current study results previous studies were also documented that camels are quite as susceptible as other livestock species to various disease conditions [36, 37].

In this study the prevalence of uterine lesions was greater in dromedary camels than in cows, even if a previous report showed an opposite trend [27]. The variation between studies might be attributed to the differences in season, management, geographical environment, level of nutrition and health management of animals. In the current study endometritis was the major uterine lesion observed in dromedary camels. As it is documented elsewhere, this could be attributed to different factors like repeated insults of the uterus due to improper mating practices [38], postpartum complications and unsanitary gynecological manipulations [5]. In the current study also almost all of the examined animals were brought to the abattoirs and slaughter houses because they were having one or more reproductive problems and are no more productive.

In the present study occurrences of chronic endometritis varied within age groups, for both female dromedary camels and cows. Adult female dromedary camels and cows were positive to chronic endometritis than other age groups of animals which was in accordance with the study report of Waheed et al. [39]. This might be due to the fact that adult female dromedary camels and cows are considered to be associated with increased frequency of mating, parturitions and/or repeated postpartum complications than other age groups. One case of uterine leiomyoma was observed in one cow. Similarly, various previous studies were also reported uterine leiomyoma in cows [40, 41 and 42]. The etiology of the uterine leiomyoma is not clearly known [40]. The current study result revealed that the cellular makeup of leiomyoma was smooth muscle neoplastic cells accompanied by varying quantities of connective tissue lacking glandular component. This was in agreement with the report of Kennedy and Miller [43]. Moreover, similar finding was also reported in female dromedary camels [10].

In the present study, the prevalence of ovarian lesions of cows were almost twice than in dromedary camels. This might be attributed to the high production potential of the Holstein Friesian breeds of cows and Holstein Friesian cross-breed cows which were highly selected for milk yield. According to the reports of Opsomer et al. [44] and Butler [45], dairy cows that were exposed to negative energy balance especially at early lactation and with higher milk yield were considered to be at risk of developing ovarian disorders. As to our knowledge, most of the dairy cows in Ethiopia were owned by small holder farmers with poor management practices in which exposure to different reproductive problems is inevitable.

The present study showed higher prevalence of follicular cysts in cows than in dromedary camels. Although dromedary camels ordinarily are liable to develop follicular ovarian cysts in the absence of coitus [46], the result of the current study might be associated to various influencing factors like level of milk production; feeding, management and exercise affect the prevalence of cystic follicle in cattle [47]. Though it is difficult to determine the exact cause of ovarian follicular cysts, it can be realized that they develop when one or more follicles fail to ovulate and subsequently fail to regress maintaining growth and steroidogenesis $[48,49]$.

In this study the prevalence of follicular cyst in both species of animals was found to be vary in relation to the different body condition scores in which the frequency of development of follicular cyst was found to be higher in animals with good body condition. This was in agreement with earlier reports by Tibary and Anouassi [23] and Abalti et al. [7] in which camels and zebu cattle with ovarian cysts had a general body condition fair to good. Microscopically, degeneration of surrounding theca and granulosa cells were seen in both species which was comparable with various previous reports $[10,11,20,34]$.

In the present study the prevalence of luteal cyst was lower than that of follicular cyst in both species of animals. This might be due to the fact that luteal cyst originate from luteinization of follicular cyst, which occurred as a result of transformation of the granulosa cells into lutein cells [10]. Moreover, they are often considered to be the later form of ovarian follicular cysts and therefore the causes pertaining to follicular cysts can also be considered the original causes

Page $9 / 24$ 
of luteal cysts [49]. The macroscopic and microscopic findings of the present study was in line with previous reports [10, 20].

In this study, ovarian bursal adhesion was only seen in cows and this might be associated to pregnancy complications. According to the report of Roberts [50], extreme adhesions have probably resulted from pregnancy complications that include retained fetal membranes and endometritis. Furthermore, this lesion can also result from hemorrhage due to harsh manipulation of the ovaries or attempts to rupture an ovulatory hemorrhagic follicle or also may result from oophoritis, ovarian hydrobursitis and peritonitis [23]. The prevalence of ovarian bursal adhesion observed in this study was in agreement with previous reports of Abalti et al. [7], Ali et al. [17] and Mekibib et al. [9], however, was higher than the report of Hatipoglu et al. [34]. The variation observed might be attributed to the difference in breed, management and level of nutrition.

Comparable cases of para-ovarian cysts were recorded in the examined dromedary camels and cows. Para-ovarian cysts are suspected to arise from persistent embryonic structures which are vestiges of wolfian ducts [20]. Para-ovarian cysts in cows are considered to be not interfere with the reproductive performance of the animal unless it leads to compression of the lumen of the oviduct $[51,52]$.

In the present study inactive ovary was observed with low frequency in dromedary camels than cows. This might be related to seasonal breeding behavior of the camelids and the current study was carried out during which most camels were cyclic. The study by Monaco et al. [53] also justified that peak sexual activity of dromedary camel ranges from November to February. Moreover, microscopically, complete absence of follicular or luteal development and excessive fibrous connective tissues proliferation was observed which was in agreement with previous reports [10, 11].

In the present study oophoritis was observed only in cows and the finding was in line with the report of camel oophoritis by Mahmoud et al. [20]. As it is documented by Fathalla et al. [54], oophoritis seems to be a rare pathological condition of bovine ovary while peri-oophoritis is commonly found. The prevalence of hydrobursitis in camel during this study was approximately similar to that of Al-Afaleq et al. [19]. However; it was lower than the report by Ali et al. [18] and Mohammed et al. [6]. The macroscopically the findings of this lesion were in line with that reported by Mohammed et al. [6]. Available sources indicated that the incidence of hydrobursitis is relatively higher in animals with a background of reproductive failure which is also true in our cases in which case almost all of the slaughtered animals were with a history of reproductive failure [55].

The frequency of oviduct affections in the present study was low in both species. In this study hemosalpinx was observed in both animal species and was in agreement with previous reports $[26,56]$. In this finding pyosalpinx was accompanied with suppurative endometritis and this supports the report by Kennedy and Miller [43] who reported pyosalpinx occurs following ascending infection. Moreover, Tibary and Anouassi [57] considered that untreated uterine infections can lead to irreversible changes in oviducts thus resulting in sterility due to occlusion. Regarding to the detected pathological changes in the cervix, cervicitis was seen in two examined animals in both species. The low frequency of cervical affections may be due to good defense action of the mucous secreting epithelium of the cervix against bacterial invasion [58]. All observed cervicitis in the present study were associated with uterine affection or inflammation of endometrium and this finding was in line with the report by Shawky et al. [10].

The pathological changes of vagina of cows and dromedary camels observed in this study were less frequent compared to uterine and ovarian lesions. This low frequency might be attributed to various factors of which the protective effect of stratified squamous epithelium of vaginal mucosa which proliferates and matures under the influence of estrogen and become more resistant to infection is of great concern. Furthermore, local production of lactic acid which deposit into the epithelium is also considered [58]. The relatively higher frequency of vaginal lesions in female dromedary camels than in cows might be associated to traumatic injury during coitus [57]. Furthermore, [5] justified that the ethno-veterinary 
practices by herdsmen using unusual substances, like dates, black seeds, and salts might be irritant to the mucus membrane and leads to vaginal lesions in dromedary camels.

The current study also tried to isolate possible bacterial species from the affected uterus of both animal species and observed that the bacteria isolated from dromedary camel's uteri were similar to those in cows. This might be associated with the camels' husbandry practices in many parts of camel producing areas in Ethiopia and also other parts of the world, which allow them to graze together with other ruminants and mingling with them at watering points or market places, thereby creating conducive environment facilitating transmission of infectious pathogens circulating among livestock species cohabiting within the same ecologic zone [59,60,61,]. The bacteria isolated from endometritis might be suspected as the main causes of endometritis in both species. This finding was in support of the report by Tibary [62] who reported resistance of the uterus to infection and its ability to rid itself of microorganisms was diminished in the presence of degenerative changes in the endometrium.

The most common bacterial species isolated from cows and dromedary camels uterine with edometritis were Staphylococcus, Streptococcus, Salmonella and Klebsiella species and Escherichia coli. This finding was similar to the report of Mshelia et al. [37]. As it is reported by Foldi et al. [63], most of the aforementioned bacterial species were attributed to the majority of the clinical reproductive disorders. Proteus and Pseudomonas species were isolated only from uterine lesion of dromedary camels and was in agreement with previous reports by Simenew et al. [11] and AlAfaleq et al. [19].

\section{Conclusion And Recommendations}

This study revealed one or more pathological abnormalities in reproductive organs of dromedary camels and cows slaughtered at Addis Ababa and Adama Municipal abattoirs and Akaki slaughter house. Uterine lesions were the major pathological disorders observed in dromedary camels while ovarian lesions were the most frequent in cows. Important bacterial species were isolated from uterine lesions of both animal species examined. These observed microbial agents are considered important causes of uterine disorders in these animal species and have to be investigated in susceptible females during the evaluation of animals pre-breeding status. Also, most of the pathological reproductive abnormalities detected in this study might be a cause of infertility in these animals being the major reason for them to be considered for slaughtering. Thus, it is important that female animals should routinely be evaluated bacteriologically and histopathologically against reproductive organs before their breeding seasons to have a better production outcome. Hence, reproductive health management, especially, targeting the postpartum and critical periods should be implemented. Moreover, studies involving wider number of abattoirs and animals and correlation between individual's reproductive lesions and hormonal disorders should be conducted to come up with more figurative results. Furthermore, there is a need for panoptic studies basing uterine cytobrush and uterine biopsy to correlate bacterial isolates with uterine lesions. Additionally, trainings for concerned veterinarians, technicians and animal owners on reproductive health and management for proper intervention mechanisms should be implemented.

\section{Declarations}

\section{Ethics approval and consent to participate}

Study was approved by College Review Board of Addis Ababa University college of veterinary medicine and oral consent was obtained from each abattoirs managemental board before sampling.

\section{Consent for publication}

Not applicable 
Availability of data and material

All data supporting the findings of this study are available within the article.

\section{Competing interest}

We declare that there is no competing interest.

\section{Funding}

This study was financially supported by Addis Ababa University Research and Technology transfer thematic research project entitled as "Reproductive Health Management and Dairy Technology RD/LT-038/15".

\section{Author's contribution}

Aynalem Mandefro Getahun and Tilaye Demissie Ayana generate and process the research idea and developed the proposal and analyzed the bacteriological and histopathological data and handled statistical analysis. Aynalem Mandefro Getahun and Tadesse Gidey Gebrezihar collected, processed and manipulated the samples. Bulto Giro Boru and Natnael Teshager Desta performed the histopathological investigations. Gemechu Chala Hunderra edited and organized the manuscript. All the authors read and approved the manuscript for publication.

\section{Acknowledgements}

The authors acknowledge Addis Ababa University Research and Technology transfer thematic research project entitled as “Reproductive Health Management and Dairy Technology RD/LT-038/15” for providing financial support.

We are very grateful for Mr. Tewdros Arega and Mr. Solomon Getachew in the department of veterinary pathology from National Animal Health and Diagnostic and Investigation center, for their technical assistance in the histopathology laboratory work.

We also thank Addis Ababa, Adama municipality Abattoirs and Akaki slaughter house workers for their kind reception, preparing equipment's and materials for the success of this work and good willing to use their Abattoirs.

\section{References}

[1] Arata MA. A Gross Morphological Study of Genital Organs from female Zebu Cattle in and around Jimma town (South-West Ethiopia). Int J Agro Vet and Medi Sci. 2015: 9; 300-303.

[2] Khaton R, Sarder M, Gofur M. Biometrical Studies of Reproductive Organs of Dairy Cows of Different Genotypes in Bangladesh. Asian J Ani Sci. 2015: 9; 388-395.

[3] Siddiqui HU, Ahmad A, Khan MZ. Biometrical studies of testes of ram. J Agri Soci Sci. 2005: 1; 78-79.

[4] Khanvilkar AV, Samant SR, Ambore BN. Reproduction in Camel. J Vet World. 2009: 2; 72-73.

[5] Ali A, Al-sobayil FA, Tharwat M, Al-Hawas A, Ahmed AF. Causes of infertility in female camels (Camelus dromedarius) in Middle of Saudi Arabia. J Agri Sci and Vet med. 2010: 2; 59-69.

[6] Mohammed HB, Bernard F, Rachid K. Reproductive abnormalities in female camel (camelus dromedarius) in algeria: Relationship with age, season, breed and body condition score. J Camel Prac Res. 2014: 22; 1-7. 
[7] Abalti A, Bekana M, Woldemeskel M, Lobago F. Female genital tract abnormalities of Zebu cattle slaughtered at BahirDar Town, North-Western Ethiopia. J Trop Ani Health Prod. 2006: 38; 505-510

[8] Simenew K, Bekana M, Fikre L, Tilahun Z, Wondu M. Major gross reproductive tract abnormalities in female cattle slaughtered at sululta slaughterhouse in Ethiopia. Glo Vet J. 2011: 6; 506-513.

[9] Mekibib B, Desta T, Tesfaye D. Gross pathological changes in the reproductive tracts of cows slaughtered at two abattoirs in Southern Ethiopia. J Vet Med and Ani Health. 2013: 46-50.

[10] Shawky AM, Ahmed AT, Mona Fl. An abattoir survey of female genital disorders of camels (Camelus Dromedaries) in Kalyoubia, Egypt. $1^{\text {st }}$ Annual Conference Moshtohor. 2004: 1; 342-356.

[11] Simenew K, Moa M, Ashenafi F, Tilaye D, Fekadu R et al. Pathological and Bacteriological Study on Abnormalities of Female Internal Reproductive Organ of Camelus dromedarius Slaughtered at Akaki Abattoir, Ethiopia. Am-Eur J Sci Res. 2015: 10; 193-202

[12] Thrusfield M. Abattoir as Source of Data Veterinary Epidemiology 2nd edn. Black Well Science Ltd. Cambridge, USA, 1995: 146-148.

[13] Buregelt CD. Color atlas of reproductive pathology of domestic animals. 1997; Mosby, Philadelphia.

[14] Gebrekidan B, Yilma T, Solmon F. Major causes of slaughter of female cattle in Addis Ababa Abattoir enterprise, Ethiopia. Ind J Ani Res. 2009: 43; 271-274.

[15] Chaudhari SU, Pau-Bakko B. Reproductive status, pregnancy wastage and incidence of gross genital abnormalities in cows slaughtered at Maidughuri abattoir, Niger. Pak Vet J. 2000: 20; 203-205.

[16] Tafti A, Darahshiri M. Studies on the uterine abnormalities of slaughtered non-pregnant adult cows. Ind Vet J. 2000: 77; 1059-1062.

[17] Ali R, Raza AM, Tabbar A, Rasool HM. Pathological studies on reproductive organs of zebu cow. J Agri and Soc Sci: 2006: 2; 91-95.

[18] Ali A, Mehana EE, Ahmed AF, El-Tookhy O, Al-Sobayil A et al. Ovarian hydrobursitis in female camels (Camelus dromedarius): clinical findings, histopathology and fertility after unilateral surgical ablation. Therio. 2011: 76; $492-499$.

[19] Al-Afaleq Al, Hegazy AA, Hussein MF, Al-Dughaym AM. Pathological disorders of the female reproductive system in slaughtered camels (Camelusdromedarius) in Saudi Arabia. J Comp Clin Path. 2012: 21; 245-251.

[20] Mahmoud MH, Fahad AA, Mostafa MH. Pathologic Studies on ovarian abnormalities in Nagas (Camelus Dromedarius) in Al-Ahsa, Saudi Arabia. Sci J King Faisal Univ. 2011: 12; 265-276.

[21] Wajid SJ. A Pathological Abattoir Survey of the Reproductive Tracts of non-pregnant Camels (Camelus dromedaries) in Iraq. J Phar and Bio Sci. 2015: 10; 84-90.

[22] Mustafa MY, Chaudhry HR, Chaudhry M, Rashid HM, Khan SA. Biometry and Pathology of Internal Genital Organs of Female Camel (Camelus Dromedarius) in Lahore, Pakistan. Imper J Interdisc Res. 2016: 2; 2454-1362.

[23] Tibary A, Anouassi A. Retrospective study on an unusual form of ovario-bursal pathology in the camel (Camelus dromedarius). Therio. 2001: 56; 415-424. 
[24] Gani MO, Amin MM, Alam MG, Kayesh ME, Karim MR et al. Bacterial flora associated with repeats breeding and uterine infections in dairy cows. Bangl J Vet Med. 2008: 6; 79-86.

[25] Hasan MA, Mamun AA, Uddin AA, Zakir MD, Hassan MZ et al. Investigation into gyneco-pathological disorders and identification of associated bacteria from the genital organs of cows in Dinajpur, Bangladish. J Adv Vet and Ani Res. 2015: 2; 165-169.

[26] Azawi OI. Postpartum uterine infection in cattle. Ani Repro Sci. 2008: 105; 187-208.

[27] Mshelia GD, Abba Y, Voltaire YA, Akpojie G, Mohammed H et al. Comparative uterine bacteriology and pathology of camels (Camelus dromedarius) and cows in north-eastern Nigeria. J Comp Clin Path. 2012: 11; 234-261.

[28] Puck A, Soliame R. Dairy Cattle Husbandry. $2^{\text {nd }}$ edit., Agromisa foundation, Wagenineger, Netherland. 2004:70-75.

[29] Nicholson MJ, Butterwort MH. A Guide to Condition Scoring of Zebu Cattle. International Livestock Reserch Center for Africa, Addis Ababa, Ethiopia. 1998.

[30] Feyissa T, Bekana M. A gross morphological abattoir study of genital organs from female crosses breed and Zebu cattle. Israel J Vet Med. 2000: 55; 83-87.

[31] Jenberie S, Awol N, Ayelet G, Gelaye E, Negussie H et al. Gross and histopathological studies on pulmonary lesions of camel (Camelus dromedarius) slaughtered at Addis Ababa abattoir, Ethiopia. J Trop Ani Health Prod. 2012: 44; 849-854.

[32] Talukder S. Histopathology techniques, tissue processing and staining. 2007: http://www.talukderb.com

[33] Quinn PJ, Markey BK, Carter ME, Donnelley WJ, Leonard FC. Clinical Veterinary Microbiology disease. Black well, London, 2004: 76.

[34] Hatipoglu F, Kiran MM, Ortatatli M, Erer H, Çiftçl KM. An abattoir study of genital pathology in cows: Department of Pathology Faculty of Veterinary Medicine University of Selcuk. Rev de Méd Vét. 2002: 153; 29-33.

[35] Dalling T, Robertson A, Boddie G, Spruell J. Diseases of camels. In: The international encyclopedia of veterinary medicine. W Green and Son Edinburgh, 1998: 585.

[36] Abbas B and Agab H. A review of camel brucellosis. J Prev Vet Med. 2002: 55; 47-56.

[37] Gwida M, El-Gohary A, Melzer F, Khan I, Rosler U. Brucellosis in camels. J Res Vet Sci. 2011: http://doi:10.1016/ 05002

[38] Tibary A, Fite C, Anouassi, Sghiri A. Infectious causes of reproductive loss in camelids. Therio. 2006: 66; 633-647

[39] Waheed MM, Hamouda MA, Al-Dughaym AM. Uterine histopathological findings of infertile female camels (Camelus dromedarius). J Camel Pract Res. 2009: 16; 1-7.

[40] Sendag S, Cetina Y, Alana M, Ilhana F, Eskia F et al. “Cervical leiomyoma in dairy cattle”. J Ani Repro Sci. 2008: 103; 355-350.

[41] Timurkaan N, Aydin M, Yilmaz F, Cevik A. Vaginal fibro-leiomyoma in a cow: a case report. J Vet Med. 2009: 54; 138141.

[42] Arvind S, Adarsh K, Sheikh I, Pankaj S, Rajesh K. "Ultrasonographic, Surgical, and Histopathological Findings of a Uterine Leiomyoma in a Cow." Case Reports in Vet Med. 2012: 42; 4-8. 
[43] Kennedy PC, Miller RB. The Female Genital System. In: Pathology of Domestic Animals, Jubb, Kennedy, Palmer Eds., Academic Press, NewYork, 1993: 349-470.

[44] Opsomer G, Grohn YT, Hertl J, Coryn M, Deluyker H et al. Risk factors for post-partum ovarian dysfunction in high producing dairy cows in Belgium: A field study. Therio. 2000: 53; 841-857.

[45] Butler W. Energy balance relationships with follicular development, ovulation and fertility in postpartum dairy cows. Livest Prod Sci. 2003: 83; 211-218.

[46] Tibary A, Anouassi A. Ultrasonographic changes of the reproductive tract in the female camel (Camelus Dromedarius) during the follicular cycle and pregnancy. J Camel Pract Res. 1996: 3; 71-90.

[47] Herenda D. Abattoir survey of reproductive organ abnormalities in beef heifers. Canada Vet J. 1987: 28; 33-36.

[48 Hegazy AA, Ali A, Al-Aknah M, Ismail S. Studies on pituitary- ovarian axis in the female camel with special reference to cystic and inactive ovaries. J Cam Sci. 2004: 16-24.

[49] Vanholder T, Opsomer G, Kruif A. Aetiology and pathogenesis of cystic ovarian follicles in dairy cattle: a review. Repr and Nutr Dev. 2006:105-119.

[50] Roberts SJ. Veterinary Obstetrics and Genital Diseases. $3^{\text {rd }}$ edit., Roberts SJ -Woodstock, NewYork.1986: $381-359$.

[51] Alam M G S. Abattoir studies of genital diseases in cows. J Vet Rec. 1984: 195-196.

[52] Peter AT, Levine H, Drost M, Bergfelt DR. Compilation of classical and contemporary terminology used to describe morphological aspects of ovarian dynamics in cattle. Therio. 2009: 1343-1357.

[53] Monaco D, Padalino B, Lacalandra GM. Distinctive features of female reproductive physiology and artificial insemination in the dromedary camel species. Emi J Food and Agri. 2015: 328-337.

[54] Fathalla M, Hailat N, Lafi SQ. An abattoir survey of gross reproductive abnormalities in the bovine genital tract in Northern Jordan. Israel J Vet Med. 2000: 1-7.

[55] Tibary A, Anouassi A. Reproductive disorders of the female camelidae. In: Tibary A (ed) Theriogenology in camelidae: anatomy, physiology, BSE, pathology and artificial breeding: actes editions. Reports of Agronomy and Veterinary Institute Hassan; 1997: 317-368.

[56] Fetaih H. Some pathological studies on the affections of genital system of she-camel. PhD Thesis, Faculty of veterinary medicine, Suez Canal University. 1991

[57] Tibary A, Anouassi A. Reproductive disorders in the female camelid. In: Recent advances in camelid reproduction, Skidmore JA, Adams GP Eds., International Veterinary Information Service. 2000: http://www.ivis.org/, access 22/6/2014.

[58] Jubb KVF, Kennedy PC, Palmer N. Pathology of domestic animals. In: $4^{\text {th }}$ San Diego, Eds., Academic press: California, London.1993

[59] El-Yuguda AD, Abubakar MB, Baba SS, Ngangnou A. Competitive ELISA rinderpest virus antibody in slaughtered camels (Camelus dromedarius): implication for rinderpest virus elimination from Nigeria. Afr J Biom Res. 2010:83-85. 
[60] Tadesse, Y., Urge M., Abegaz S., Kurtu Y.M., and Kebede K. Camel and cattle population dynamics and livelihood diversification as a response to climate change in pastoral areas of Ethiopia. 2013: 25; 166. Livestock research for rural development.

[61] Tefera, M., Abebe, G., (eds). Camel in Ethiopia. Ethiopian Veterinary Association. 2012: 188.

[62] Tibary A. "Infertility in female Camelids." Reproductive patterns and examination technique. Large Animal Proceedings of the North American Veterinary Conference, January $17^{\text {th }}-21^{\text {st }}, 2004: 18: 285-286$.

[63] Foldi J, Kulcsar M, Pecsi A, Huyghe B, DeSa C et al. Bacterial complications of postpartum uterine involution in cattle. Ani Repro Sci. 2006: 96; 265-281.

[64] Lacey, M. and Rosenberg, F. Cystic Ovaries in Dairy Cattle California Polytechnic State University, San Luis Obispo. 2010:1-6

[65] Tsianos, G.P., Stefania, M. M., George K. and Theodor S. Pyosalpinx a Case Report. J Vet Med. 2011: 5: 546-546

[66] Powers, B.E., Johnson, L.W., Linton, L.B., Garry, F. and Smith, J. Endometrial biopsy technique and uterine pathologic findings in llamas. J Am Vet Med Assoc. 1990: 197; 1157-1162.

\section{Tables}

Table 1: Frequency (\%) of ovarian disorders

\begin{tabular}{lllllllll}
\hline Variables & Category & $\begin{array}{l}\text { Follicular } \\
\text { cyst }\end{array}$ & $\begin{array}{l}\text { Luteal } \\
\text { cyst }\end{array}$ & $\begin{array}{l}\text { Paraovarian } \\
\text { cyst }\end{array}$ & $\begin{array}{l}\text { Inactive } \\
\text { ovary }\end{array}$ & $\begin{array}{l}\text { Ovarian- } \\
\text { bursal } \\
\text { adhesion }\end{array}$ & $\begin{array}{l}\text { Oophoritis } \\
\text { Ovarian } \\
\text { hydrobursitis }\end{array}$ \\
\hline Species & Cow & $6(4.28)$ & $3(2.14)$ & $2(1.42)$ & $4(2.85)$ & $7(5)$ & $1(0.72)$ & 0 \\
& Camel & $4(2.85)$ & $2(1.42)$ & $2(1.42)$ & $1(0.72)$ & 0 & 0 & $1(0.72)$ \\
& Young & $1(3.44)$ & $1(3.57)$ & $1(3.44)$ & $1(3.44)$ & $1(3.44)$ & 0 & 0 \\
BCS & Adult & $7(5.34)$ & $2(1.57)$ & $3(2.3)$ & $3(2.29)$ & $3(2.29)$ & 0 & 0 \\
& Old & $2(1.66)$ & $2(1.66)$ & 0 & $1(0.83)$ & $3(2.5)$ & $1(0.83)$ & $1(0.83)$ \\
& Poor & $1(0.74)$ & $2(2.27)$ & 0 & $4(4.54)$ & $2(1.42)$ & 0 & $1(1.13)$ \\
& Medium & $1(1.75)$ & $1(1.75)$ & $3(5.26)$ & 0 & $1(0.72)$ & $1(1.75)$ & 0 \\
& Good & $8(9.0)$ & $2(1.48)$ & $1(0.74)$ & $1(0.74)$ & $4(2.85)$ & 0 & 0 \\
\hline
\end{tabular}

Table 2: Frequency (\%) of uterine lesions

\begin{tabular}{llllllll}
\hline riables & Category & Cervicitis & $\begin{array}{l}\text { Acute } \\
\text { Endometiritis }\end{array}$ & $\begin{array}{l}\text { Chronic } \\
\text { Endometiritis }\end{array}$ & $\begin{array}{l}\text { Catarrhal } \\
\text { Endometiritis }\end{array}$ & $\begin{array}{l}\text { Suppurative } \\
\text { Endometritis }\end{array}$ & Leiomyoma \\
\hline ecies & Cow & $2(1.42)$ & $9(6.42)$ & $7(5)$ & $2(1.42)$ & $2(1.42)$ & $1(0.72)$ \\
& Camel & $2(1.42)$ & $12(8.57)$ & $16(11.4)$ & $2(1.42)$ & 0 & 0 \\
e & Young & 0 & $2(6.9)$ & $5(17.2)$ & $1(3.44)$ & 0 & 0 \\
& Adult & $2(1.52)$ & $11(8.39$ & $5(3.81)$ & 0 & $2(1.52)$ & 0 \\
S & Old & $2(1.66)$ & $8(6.66)$ & $13(10.8)$ & $3(2.5)$ & 0 & $1(0.83)$ \\
& Poor & $1(1.13)$ & $7(7.95)$ & $7(7.95)$ & $3(3.4)$ & $2(2.27)$ & $1(0.72)$ \\
& Medium & $1(1.75)$ & $5(8.77)$ & $5(8.77)$ & 0 & 0 & 0 \\
& Good & $2(1.48)$ & $9(6.66)$ & $11(8.14)$ & $1(0.74)$ & 0 & 0 \\
\hline
\end{tabular}

Table 3: Frequency (\%) of oviductal and vaginal lesion 


\begin{tabular}{llllll}
\hline Variables & Category & Hemosalpinx & Pyosalpinx & Vaginitis & Vaginal myositis \\
\hline Species & Cow & $2(1.42)$ & $2(1.42)$ & $2(1.42)$ & 0 \\
& Camel & $1(0.72)$ & $1(0.72)$ & $1(0.72)$ & $3(2.14)$ \\
Age & Young & 0 & 0 & 0 & 0 \\
& Adult & $2(1.52)$ & $2(1.52)$ & $2(1.52)$ & $2(1.52)$ \\
& Old & $2(1.66)$ & $1(0.83)$ & $1(0.83)$ & $1(0.83)$ \\
BCS & Poor & $2(2.27)$ & $1(1.13)$ & $1(1.13)$ & $2(2.27)$ \\
& Medium & 0 & $1(1.75)$ & $1(1.75)$ & 0 \\
& Good & $2(1.48)$ & $1(0.74)$ & $1(0.74)$ & $1(0.74)$ \\
\hline
\end{tabular}

\section{Figures}

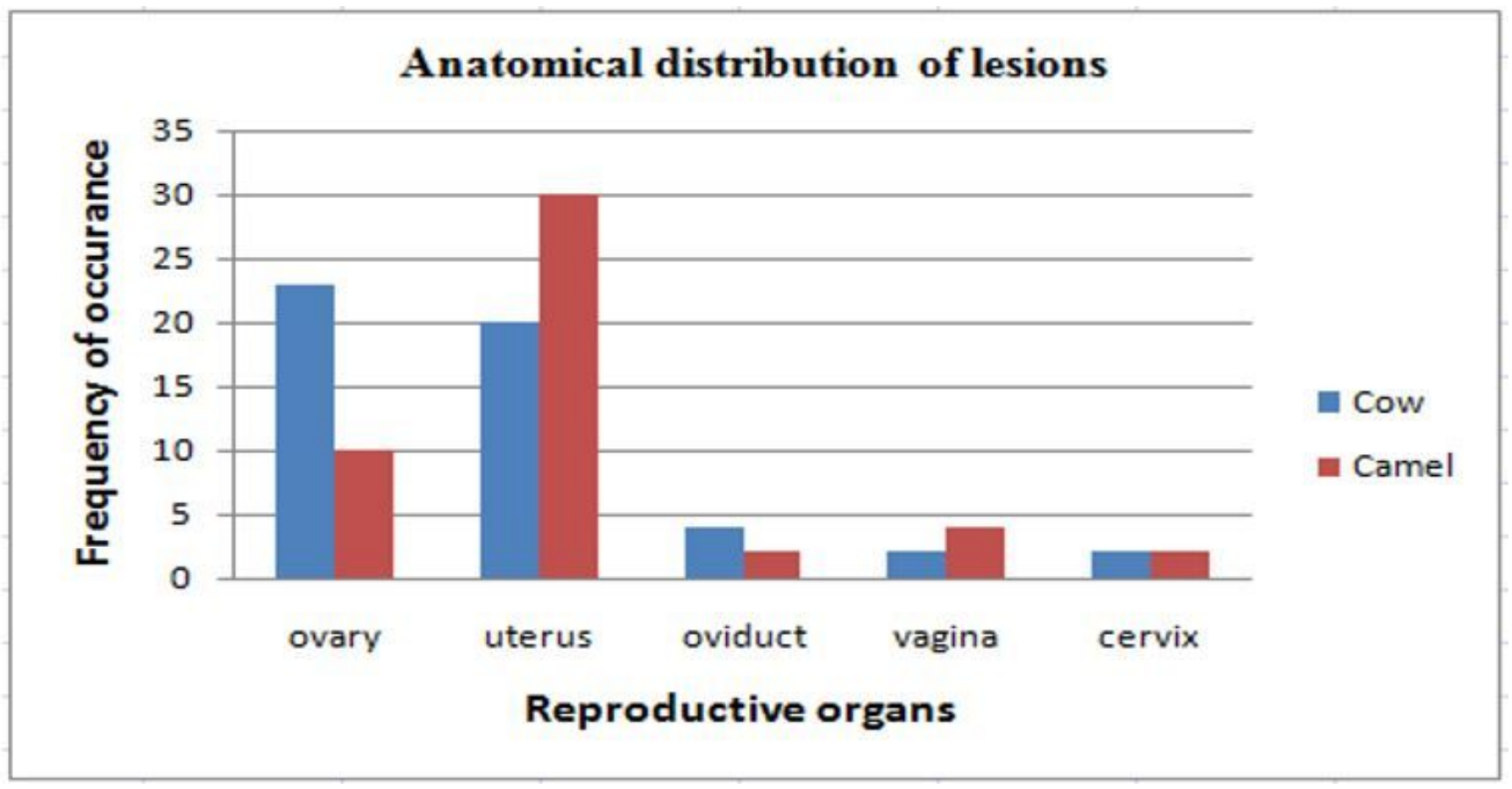

Figure 1

Anatomical distribution of reproductive organ lesions in cow and dromedary camel 

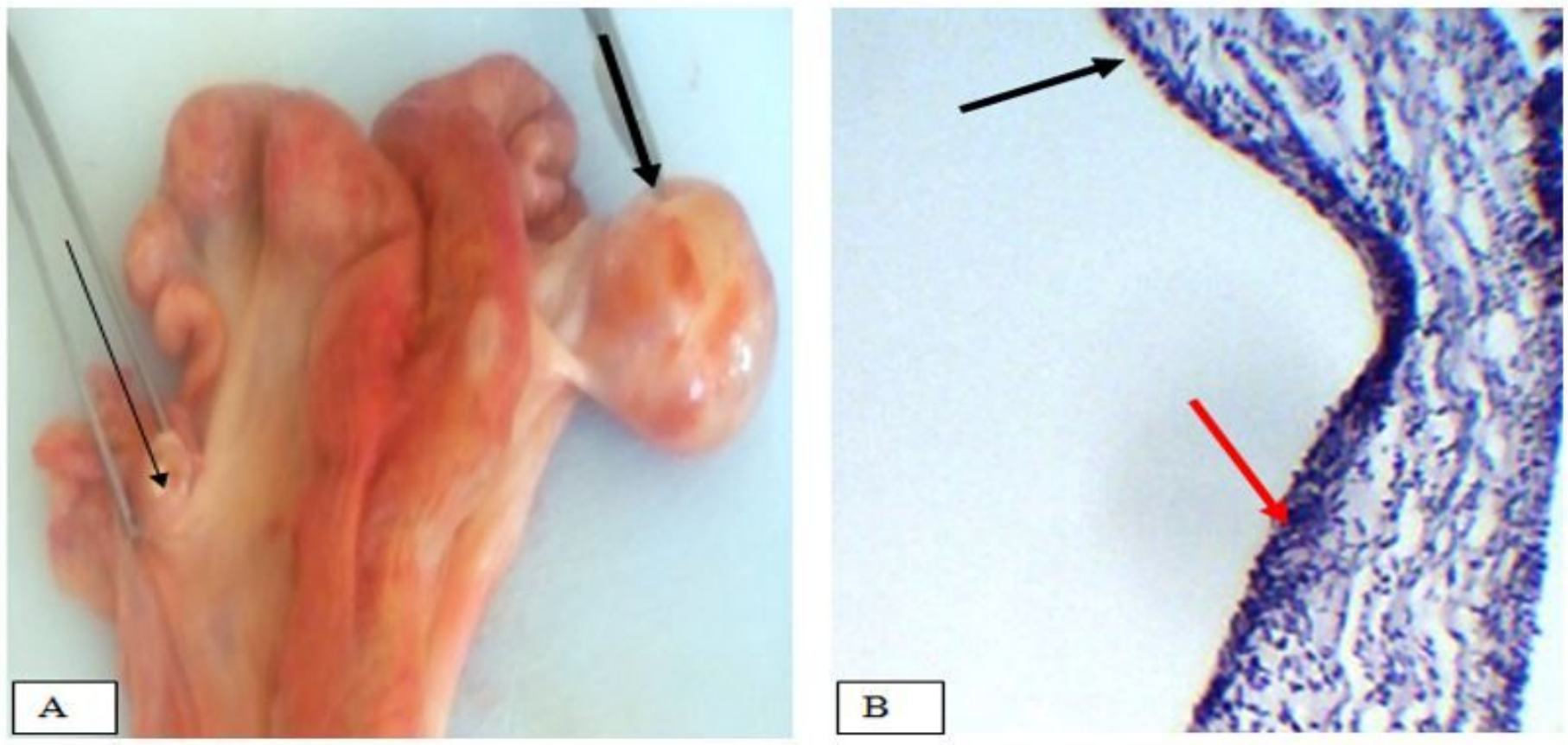

\section{Figure 2}

Follicular cysts. Note that the cyst occupies the entire right ovary and very thin wall due to distention by follicular fluid indicated by short thick arrow. The left ovary was hypoplastic indicated by thin arrow (A) which was microscopically characterized by extremely thin granulosa cells (black arrow) and red arrow indicate degeneration of granulosa cell (B). $\mathrm{H}$ and E stain X 40 .

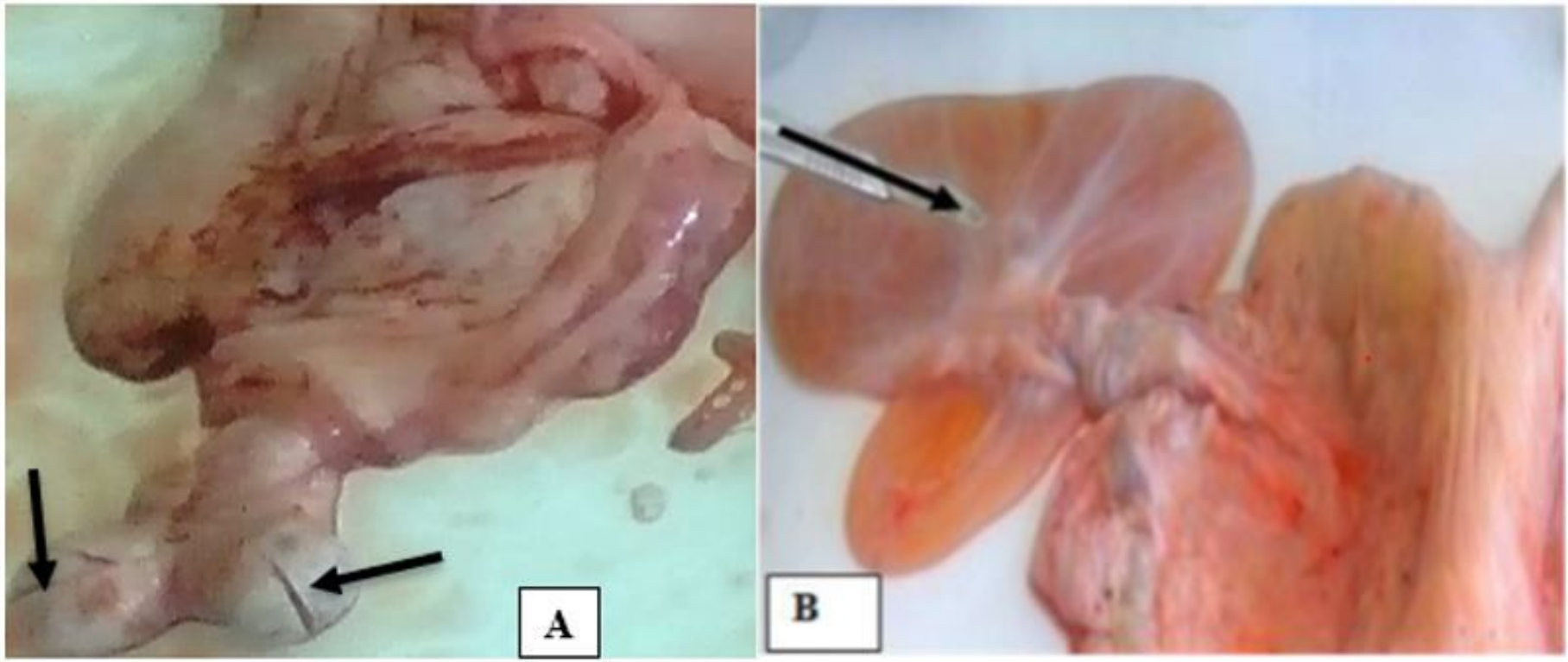

\section{Figure 3}

Macroscopic lesions. Thick walled luteal cyst indicated by arrow (A) unlike the thin wall follicular cysts (fig 2A) and macroscopic lesion of ovarian hydrobursitis, note straw colored fluid accumulation in ovarian bursa (B). 

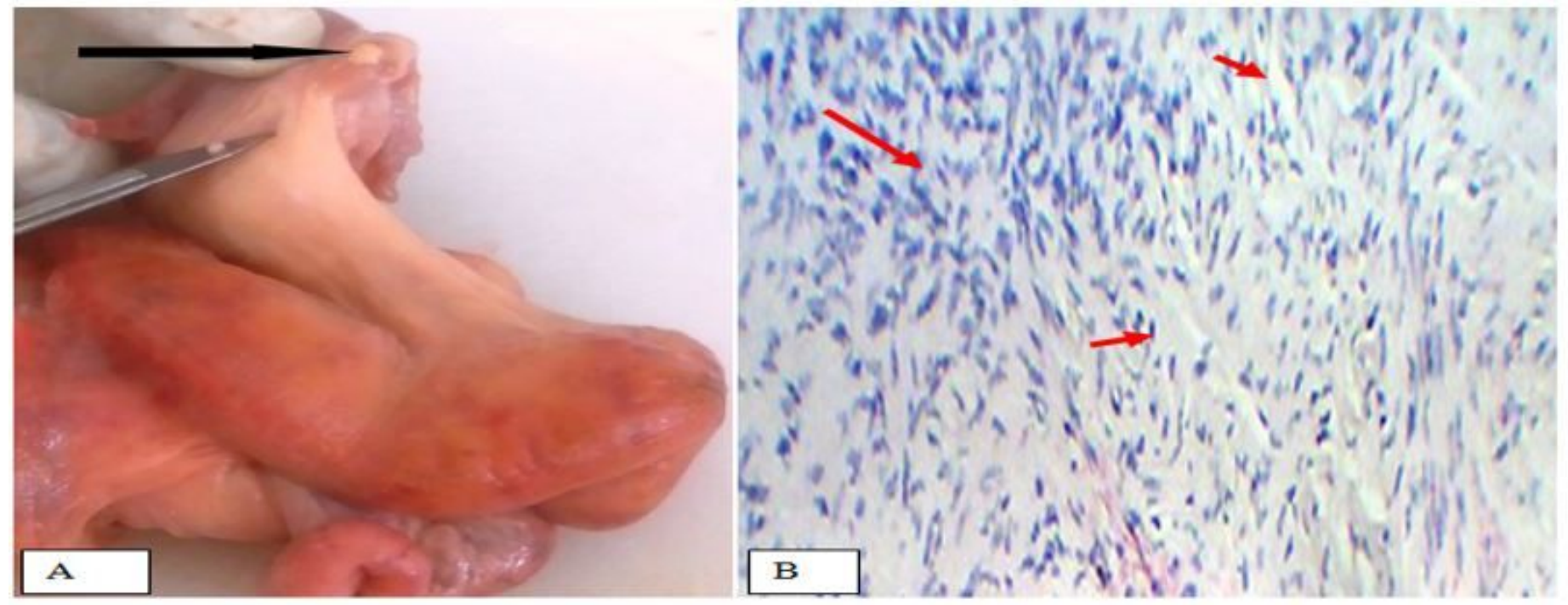

\section{Figure 4}

Hypoplastic ovary. Note the small size ovary (A) showing excessive fibrous connective tissues proliferation with complete absence of follicular or luteal development microscopically (B). H and E stain X 40
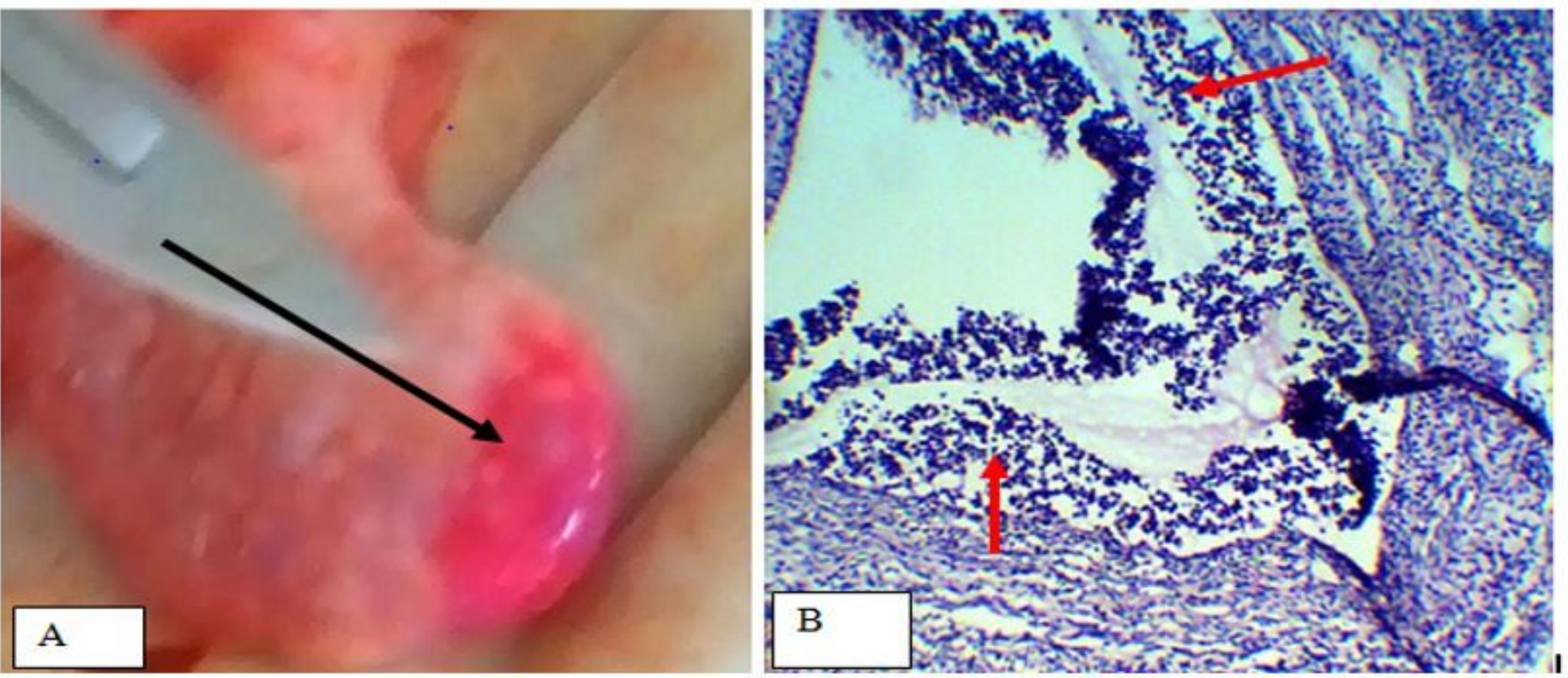

Figure 5

Oophoritis. Note hyperemic and swollen ovary $(A)$ inflammatory cells infiltrations in ovarian medullary region (B) indicated by (red arrow). $\mathrm{H}$ and $\mathrm{E}$ stain X 40. 


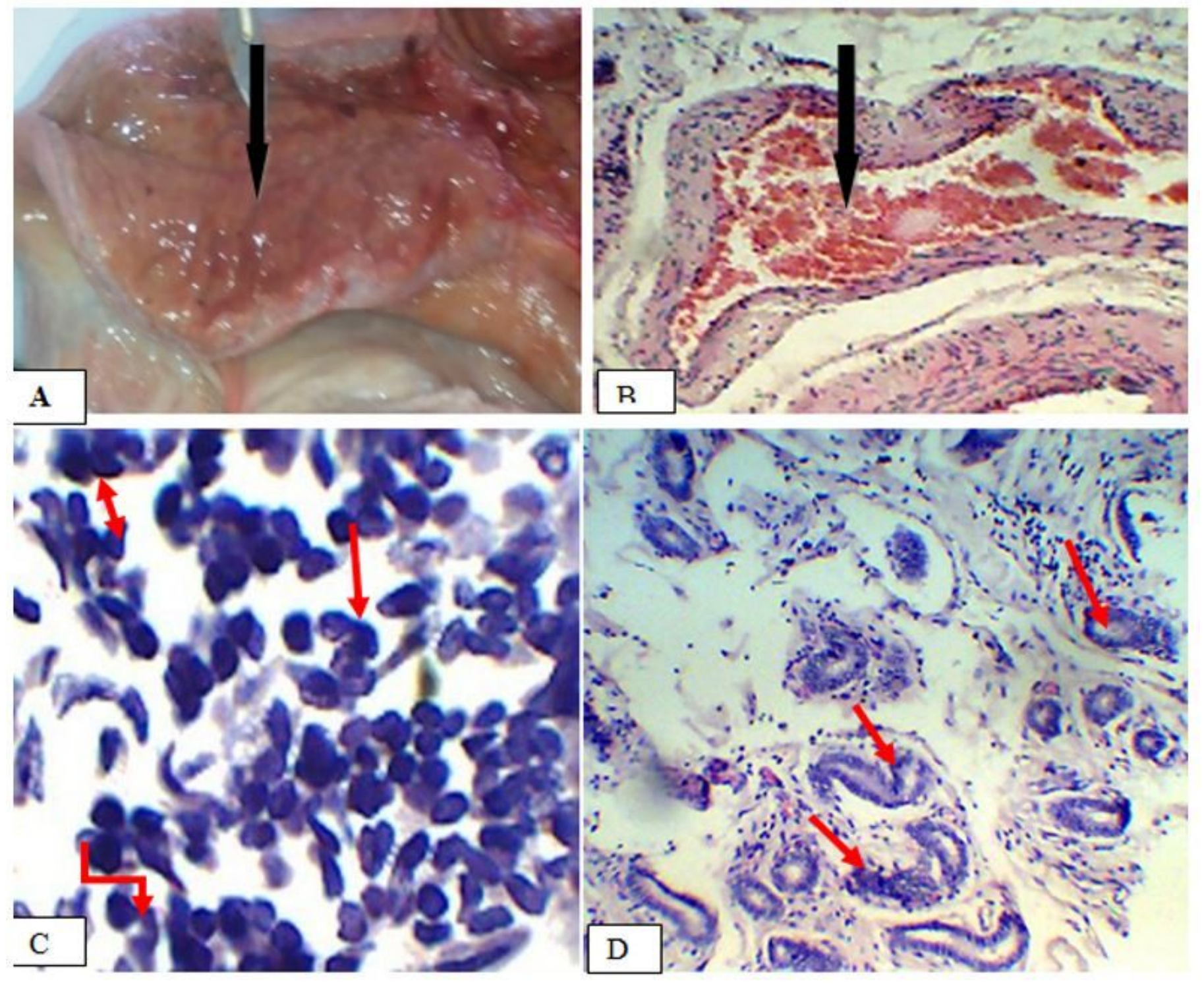

Figure 6

Severely hyperemic acute endometritis with blood tinged exudates in the upper corner $(A)$ congestion of endometrial blood vessels (B) aggregation of neutrophilis $\mathrm{H}$ and $\mathrm{E}$ stain 100X (C) misshapen and atrophied endometrial gland (D). $H$ and E 40X. 


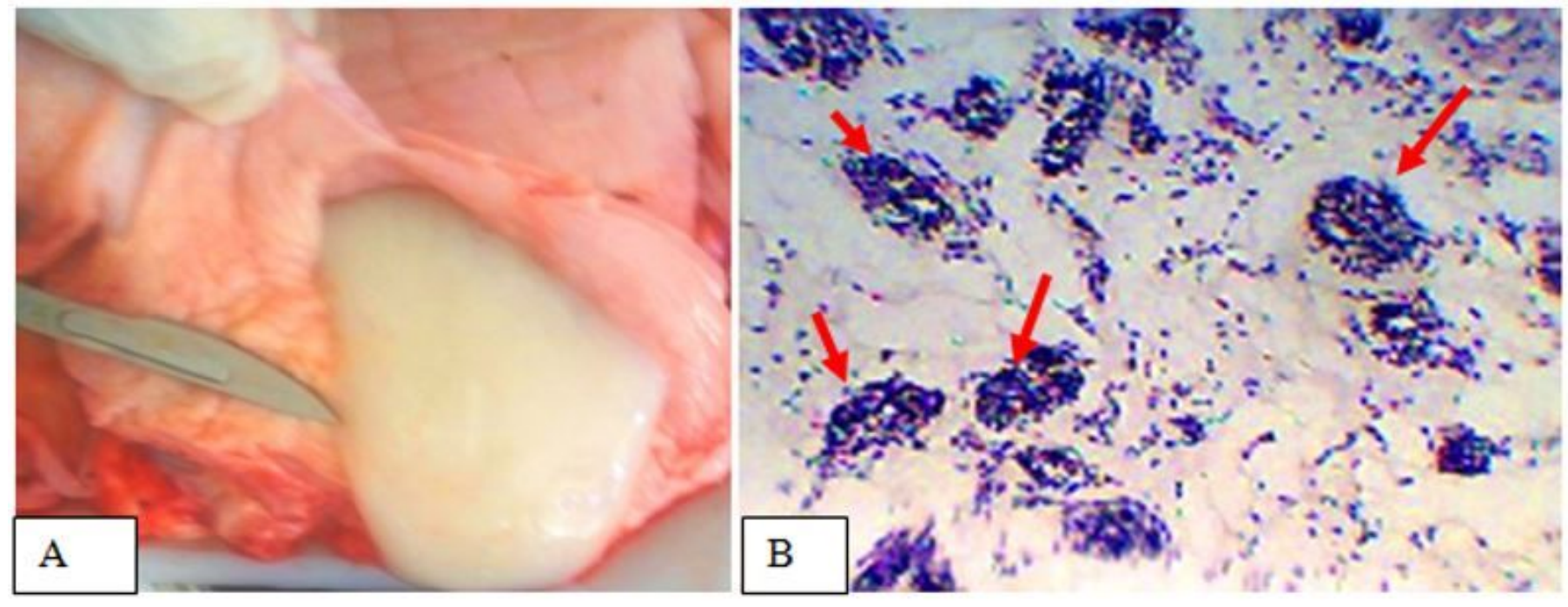

Figure 7

Catarrhal endometritis. Note the mucoid exudates discharged from vagina (A) microscopic endometrial gland degeneration (B) H and E 40X 


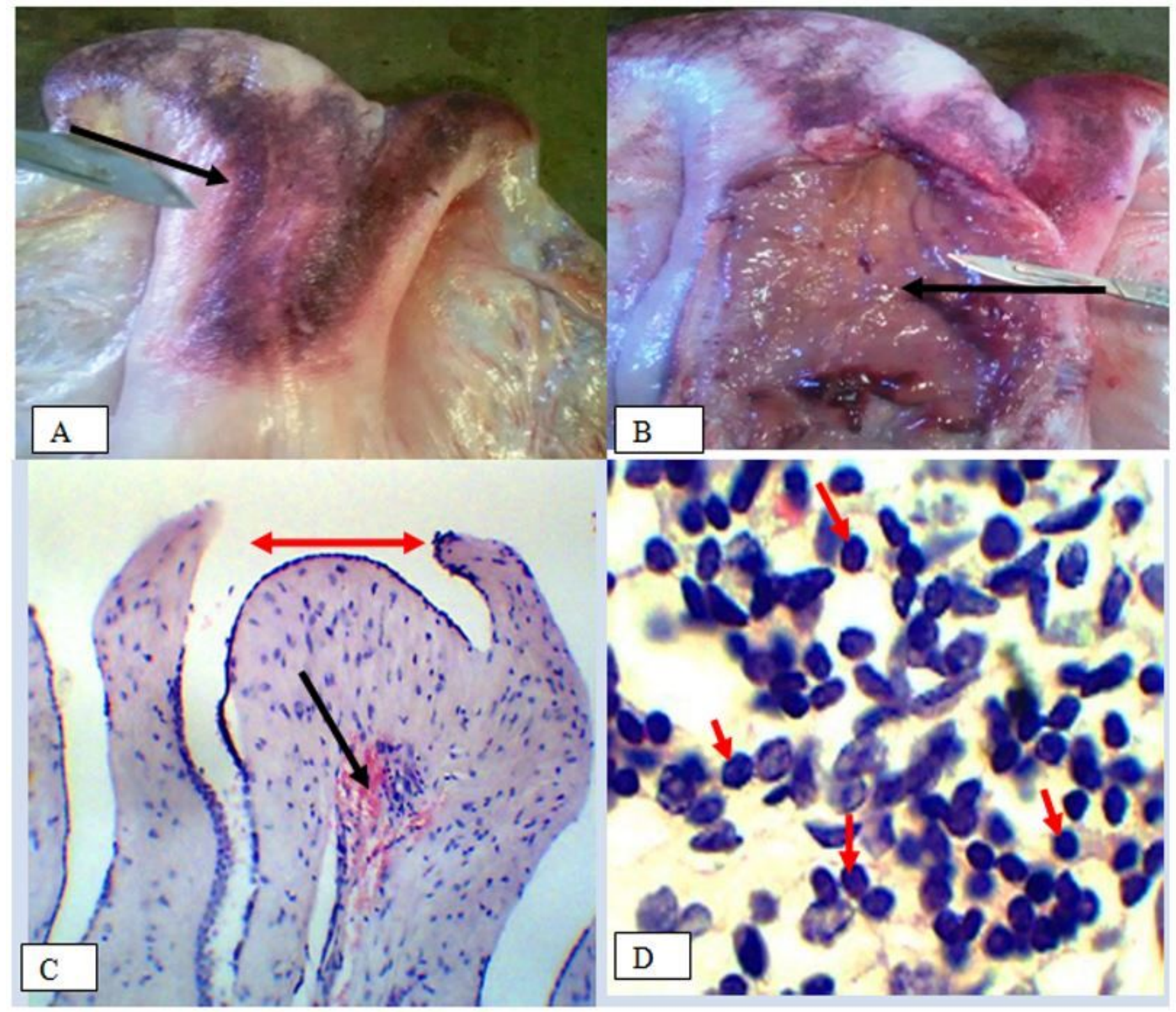

Figure 8

Chronic endometritis. Note severe congestion visible from outside (A) and severely congested and thickened mucosa on incision (B) severely hyperplastic mesetholium indicated by (red two-sided arrow) and hemorrhage (black arrow) $\mathrm{H}$ and $\mathrm{E}$ 40x (C) lymphocytes infiltrations in endometrium (D) H and E 100x 

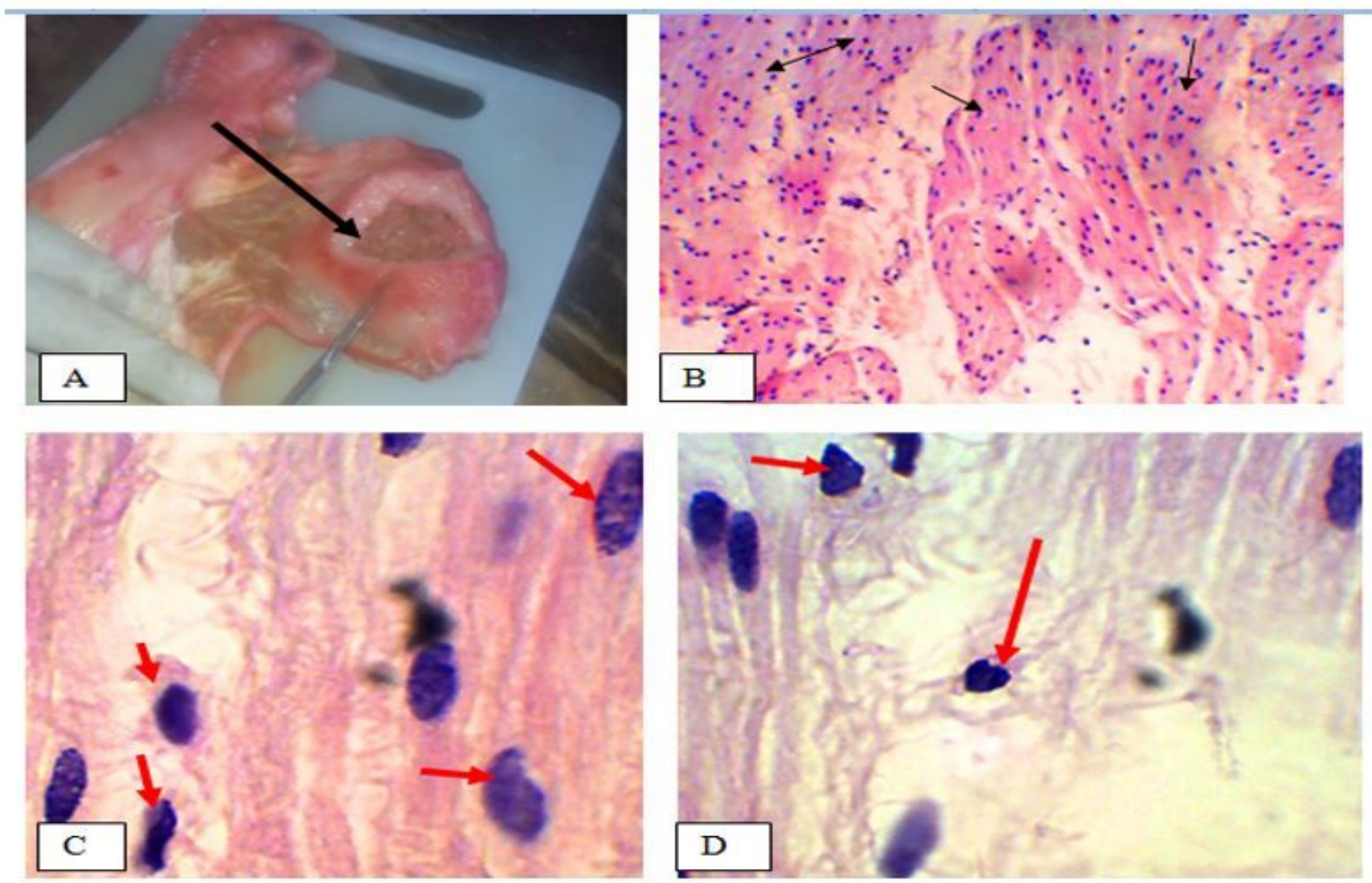

\section{Figure 9}

Leiomyoma. A firmly attached mass originated from body of uterus $(A)$ showing bundles of smooth muscles running in various directions and interlaced with each other. Hand E stain X 40 (B) variation of nucleus shape (C) slight mitotic figure (red arrow) (D). Hand E stain X100.
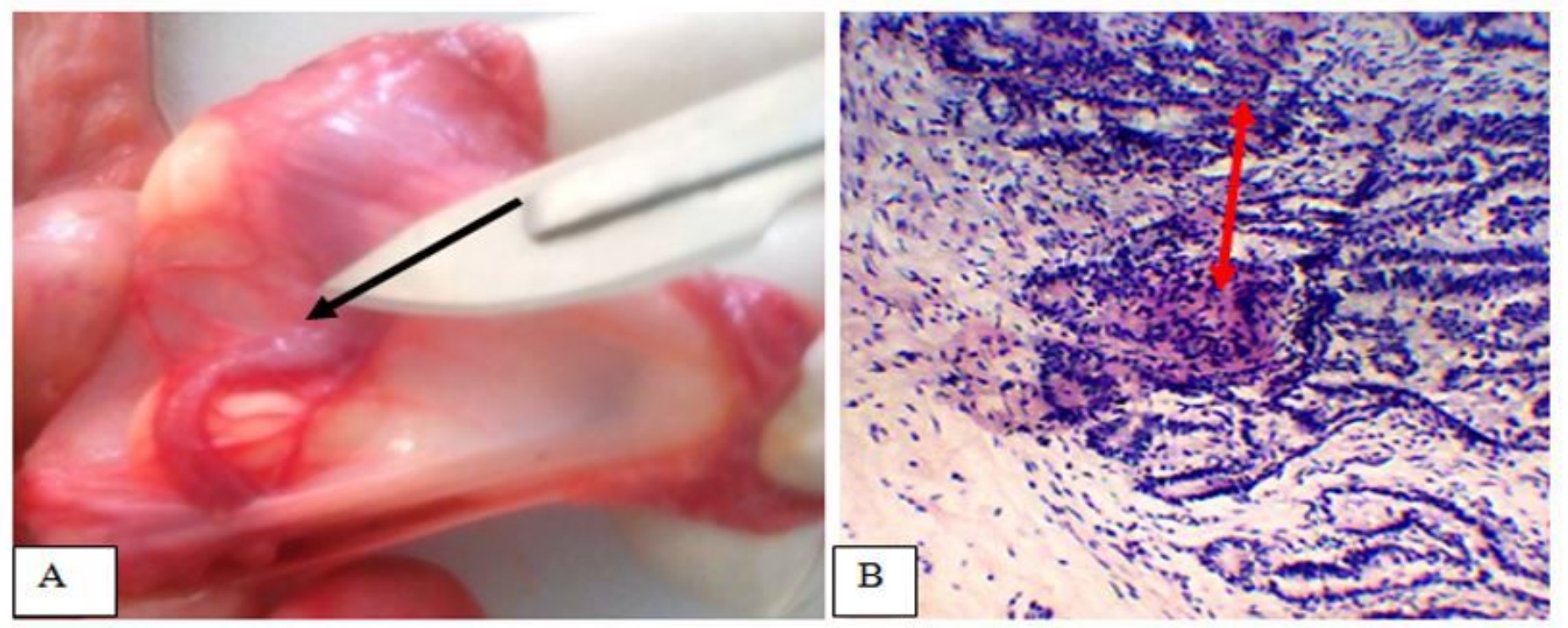

Figure 10

Hemosalphinx. Note the mucosa was hyperemic and the lumen filled with bloods (A) microscopically edema and inflammatory cell infiltrations (B) indicated by (red arrow). $\mathrm{H}$ and $\mathrm{E}$ stain $\mathrm{X} 40$. 


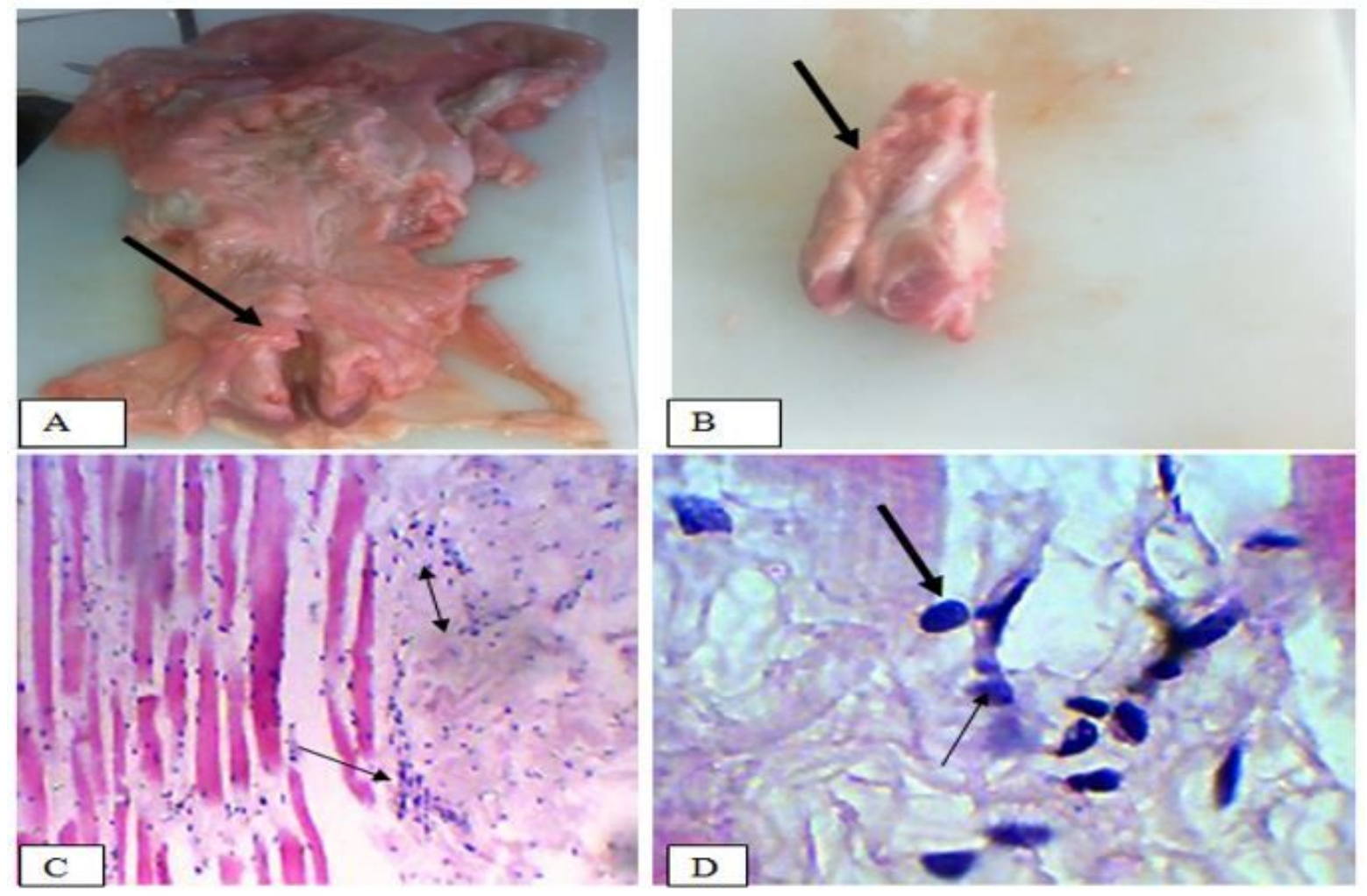

Figure 11

Vaginal myositis. A cross section of swelling mass in the wall of the vagina (A) tumor like mass after removed from the wall (B) sloughed myocytes Hand E stain X40 (C) lymphocytes infiltration between myocyte. Hand E stain X 100

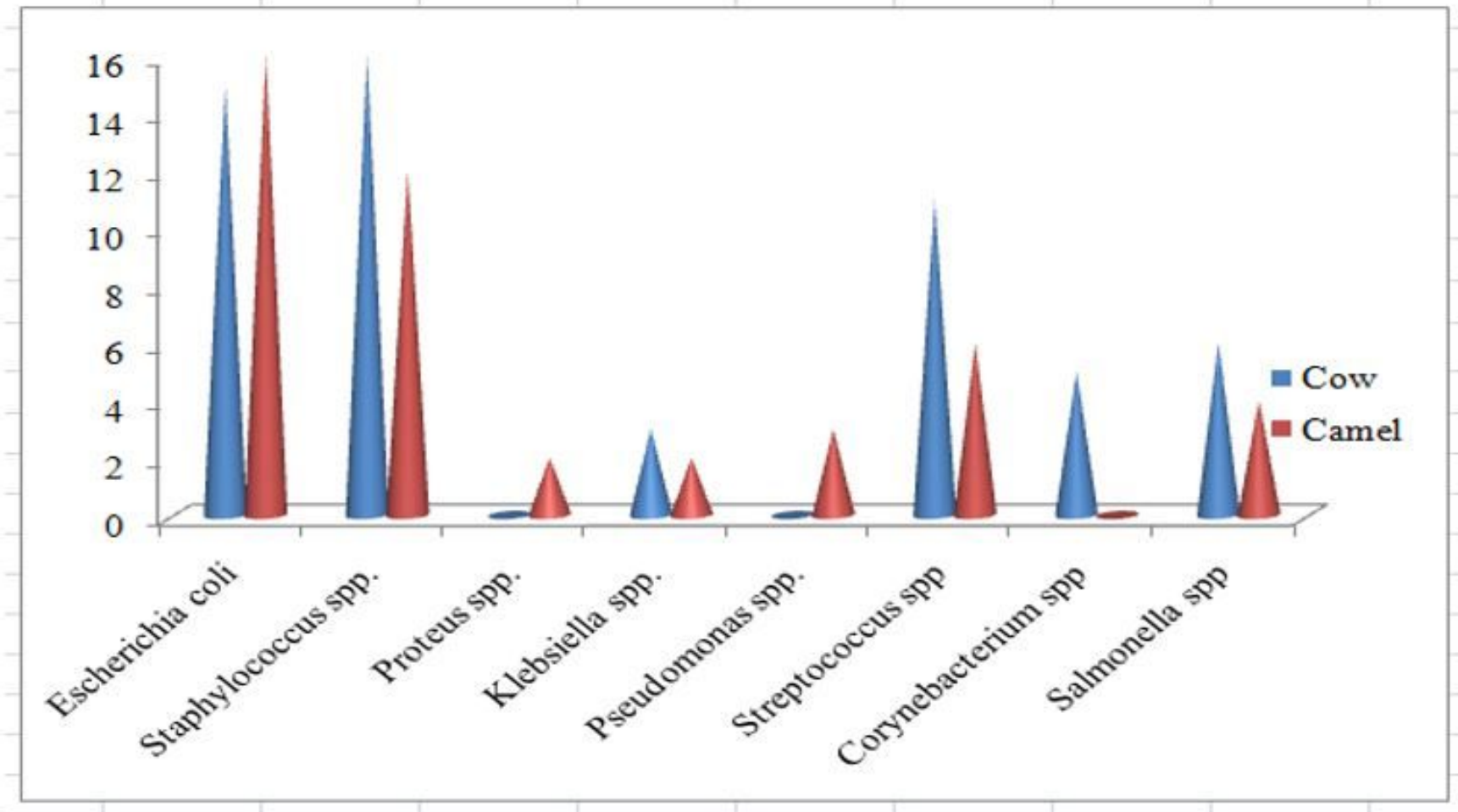

Figure 12

Graphical presentation of bacteria isolated from uterine lesions. 